Journal

of Geography

Politics and Society

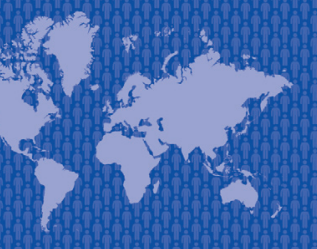

$8(3) / 2018$

\section{Journal of Geography, Politics and Society}

$2018,8(3), 18-24$

DOI 10.4467/24512249JG.18.018.8787

\title{
ASSESSMENT OF THE HEALTH LOSSES RESULTED FROM THE INTERNAL ARMED CONFLICT IN UKRAINE AND PUBLIC HEALTH TASKS
}

\author{
Natalia Ryngach (1), Olena Korolchuk (2) (3) \\ (1) Ptoukha Institute for Demography and Social Studies of the National Academy of Sciences of Ukraine, Shevchenka 60, 01032, Kyiv, Ukraine, \\ e-mail: n_ryngach@ukr.net \\ (2) Department of Social and Humanitarian Policy, The National Academy of Public Administration under to the Office of President of Ukraine, Tsedika 20, \\ 02000 Kyiv, Ukraine, \\ (3) Department of Health Systems Management, Ariel University, Ariel 40700, Israel, \\ e-mail: terrasanitas@gmail.com (corresponding author)
}

\section{Citation}

Ryngach N., Korolchuk O., 2018, Assessment of the health losses resulted from the internal armed conflict in Ukraine and public health tasks, Journal of Geography, Politics and Society, 8(3), 18-24.

\section{Abstract}

The article is devoted to the health and lives losses resulted from the armed conflict in Ukraine. It shows the real and potential consequences for the social health and determination of major (priority) activity directions and tasks for public health menagement, with the aim of their minimisation or prevention.

\section{Key words}

lives and health losses in Ukraine, internal armed conflict, public health.

\section{Introduction}

Military actions and social conflicts in the country have a bitter price, measured by the lost lives and health of its citizens. In addition to a direct threat to life during conduct of hostilities, the inevitable decadence of health in the conflict region contributes to the contravention of normal living conditions, the lack of necessary medical care (or its delay), defective medicine and forced non-compliance with the necessary treatment. Negative influence is felt by the population on the rest of Ukraine territories - due to constant stress, reduction of budget financing of health care, decrease in availability of medicines and medical services.

In 1991-2002, armed conflicts of varying intensity in the past Yugoslavia led to significant human victims - according to estimates was killed more than 125,000 and up to 3 million people were forced to change their place of residence. The breakup of the USSR also caused a series of incidents od violence. According to unconfirmed data, the collisions in Tajikistan, Abkhazia, Nagorny Karabakh, Transnistria and the North Caucasus took lives of more than 200 thousand people (Rockenschaub et al. (eds), 2007, p. 41). According to official data of the 
State Statistics Service of 2014, there are only 3,394 deaths recorded as «Damage due to hostilities», but the expert account of losses is significantly higher. Thus, the head of the United Nations Observer Mission on Human Rights Situation in Ukraine A. Harutyunyan noted that from the middle of April 2014 to February 2015 , the death of at least 5,809 people was documented, moreover, the number of deaths on the Donbass on both sides and among civilians continues to grow (Інтерв'ю голови..., 2015). If according to the Ministry of Defense data from the beginning of the antiterrorist operation and the beginning of Russian aggression against Ukraine in June 2017, 2,696 Ukrainian soldiers were killed (9,903 injured), then according to the unofficial statistics of the Book of Memory site, only 1,736 fighters of various departments and territorial battalions were killed during 2014, in 2015 - 1,117; in 2016 - 556. On Ocober, 24, 2017 their number has increased by another 244 persons (Сайт проекту «Книга Пам'яті», 2017). The statistics of deaths of the civilian population, especially those from uncontrolled territories of Ukraine, are incomplete, and health disorders are also reported in a timely or incomplete manner. The complicated current situation in Ukraine has affected the deepening of the gender imbalance of death - as more than $90 \%$ of deaths officially registered as deaths due to hostilities - the loss of life of young men. With the continuation of hostilities on the territory of Ukraine, the problem of direct and indirect losses and man's death will only aggravate.

Timely, clear and proven health system measures can save lives and health of many people. Besides those facts, health is a vital element of the recovery process: it is unreal without a healthy population. Therefore, the effective functioning of the national OZ system, which is impossible without proper, wellbalanced management, is no less important than a military or economic one, a factor in ensuring national security.

The aim of the work was to assess the loss of life and health due to the internal armed conflict in Ukraine and to identify the urgent directions and tasks for managing health care with a view to minimizing and preventing them.

\section{Research results analysis}

Routine health indicators, such as the level of morbidity and the prevalence of illnesses that are formed after applications to health care facilities, characterize it not quite reliable. This concerns to the whole country, and especially to the Donbas. After all, regardless of whether it is a territory under the control of Ukraine or as a part of self-proclaimed republics, due to difficult life circumstances, the number of applications to medical institutions is sharply reduced.

According to the Statistics Center of the Ministry of Health (Показники здоров'я..., 2015), since summer 2014, information from the Luhansk region is fragmentary (for example, in August 2014 - without data from 4 cities and 4 districts, September - without data from 7 cities and 3 districts, etc.).

However, relatively complete (in the territorial coverage) (Показники здоров'я..., 2015) statistics from Donetsk oblast demonstrated an unprecedented decrease in the prevalence of diseases: if in 2013 the level of 182,773 per 100 thousand citizents was fixed, then in 2014 the number of registered is more than twice lower!

Of course, it is not only the failure of not appealing of population (for various reasons), but also the migration outflow, and ignorance of the real quantity of population living in these territories. The decrease in morbidity, according to available statistics (Показники здоров'я..., 2015), is also striking - the number of newly diagnosed diseases per 100 thousand population fell from 60188.1 to 23685.3 ! For example, the incidence of diabetes in the Donetsk region declined by 2.8 times, psychiatric and behavioral disorders were 2.9 , circulatory system diseases 2.6, diseases of the digestive system 2.8 times, and so on. Reduction in the level of injuries is relatively less - 2.2 times. It can be assumed that, in fact, for example, health damage due to unnatural causes is higher (considering the number of fatal cases). Mortality, as opposed to morbidity, is a more reliable indicator. If we abstract from the problem of a reliable population and analyze the changes in the registered absolute number of deaths in the Donetsk region for the reasons, then we can confirm the increase in the importance of external causes (injuries, poisonings, and accidents). The number of deaths due to unnatural reasons has increased by almost 30\% compared to 2013 (while due to all reasons - by 3\%). Currently, statistics on morbidity and prevalence are available only with the Donbas territories controlled by the government. Incomplete information from the territory where about one in ten citizens is Ukrainian significantly reduces the reliability of general statistics in Ukraine, which negatively affects the quality of data for making management decisions at all levels.

One of the most urgent issues is the problem of fighting against HIV/AIDS, tuberculosis, drug addiction. According to the DU «Ukrainian Center of the Control of Socially Dangerous Diseases of the Ministry of Health of Ukraine», over 16 thousand HIVpositive people lived in the territory uncontrolled for the Government (at the beginning of 2015), 7,700 of 
whom received antiretroviral therapy (ART), more than 2.3 thousand people have an active form of tuberculosis, including more than 500 people with multi-resistant (resistant to treatment) tuberculosis. On Luly 1 in 2017, 1,660 HIV-infected persons, including 1,226 people $(73,9 \%)$ from Donetsk Oblast, 319 people (19.2\%) from Lugansk Oblast and 115 persons $(6.9 \%)$ - from Crimea arrived from settlements in the territory of which the state authorities temporarily fail to exercise their powers and are under the medical supervision of the AIDS Service in other regions of Ukraine (Оперативна інформація..., 2015).

There is a high risk of outbreaks of socially dangerous diseases in the country. Nowadays there is a worsening of the situation with HIV/AIDS due to the complicated humanitarian situation, hostilities in the eastern part of the country and the increase in the number of internally displaced persons from Donetsk and Luhansk oblasts, because these regions are among the most affected by the epidemic. Nearly 700 patients in the ATO area were forced to stop treatment under the substitution maintenance therapy program (Оперативна інформація..., 2015). When not all patients can get vital medicines, migrants may be at increased risk of returning to the use of drugs due to their difficult psychological state and difficult living conditions.

As you know, continues stay in a state of stress determines the aggravation of existing and the development of new diseases. The sociological study of the Kyiv International Institute of Sociology (Понад 90\%..., 2015) in June 2015 revealed that more than $90 \%$ of citizens living in cities not controlled by Ukraine have psychological symptoms related to «war trauma» (post-traumatic stress disorder). Residents of these territories assume that in the future there will be a need in treatment of alcoholism among the population.

A prolonged conflict situation can provoke mental health problems or worsen already existing disorders, often at the same time when the existing state infrastructure of mental health care is weakened. Some of the victims develop mental disorders that can lead to disability; many others are in condition of psychological distress. And those who previously had a mental illness often need more serious help than before an emergency.

According to the Institute of Sociology of the National Academy of Sciences of Ukraine, in 2014 in Ukraine the level of anxiety was the highest since 1996 and counted to 49.7, while in Donetsk and Luhansk oblasts -53.5 (the highest level is the index of 80 ). Among women, the rate is higher than that among men, with age it is rising, the highest anxiety is among respondents with a low level of education (Страх як міріло..., 2014; Ворона, Шульга (eds.), 2016).

The focus sociological research carried out by the Ukrainian Research Institute of Social and Forensic Psychiatry and Narcology of the Ministry of Health of Ukraine showed that one in four (24\%) of the interviewed internally displaced persons (most of them - residents of the Donbas) have depressed mood and anxiety. Clinical and psychological examination of 140 military in the Dnipropetrovsk military hospital wounded while performing official duties in the ATO area revealed, among other things, a high prevalence of depression (according to the Beck scale, the rates of depression were clinical at $23 \%$, subclinical - in $66 \%$ of cases) (Коваленко, Корнацький (eds.), 2015, p. 188).

The problem of the availability of the necessary treatment intensified - both for the whole population, especially because of the catastrophic rise in prices of medicines, and (especially!) for the population in the zone of conflict. According to the study of humanitarian needs of residents of Donetsk and Luhansk oblasts, performed at the request of the Humanitarian Headquarters R. Akhmetov, the situation with the availability of medicines is steadily difficult: more than half of the respondents reported that there is a lack of the necessary medicines. Thus, from September 2014 to June 2015, the need of medicines was even higher than in food (Сайт проекту..., 2015).

One more pressing problem is the safety of water. We remind that in 2011 only 2 outbreaks of viral hepatitis $A$ related to the water transmission factor were registered (64 people were affected, including 37 children in Bakhchysaray, Crimea, Sinelnikovo, Dnipropetrovsk region), and in 2014 - 8 outbreaks (Щорічна доповідь..., 2015). In Donetsk in 2014, compared to the previous year, the incidence of acute hepatitis A (Botkin's disease) was associated with the pollution of drinking water, a violation of sanitary rules in the manufacture and sale of food products increased in 2 points. Besides, epidemic increase was noted in 8 regions neighboring to the conflict and those who took a significant number of migrants: in Dnipropetrovsk region - 5.5 times, Zaporizhzhia region - 2 times, Kyiv region and Kyiv - more than 3 times, Kharkiv - 4 times. The Luhansk region has the largest number of water pipelines that do not meet the sanitary standards $-16.5 \%$ (in Ukraine-3.1\%).

Violations of the vaccination process and the reduction of the proportion of timely vaccinated contingent, especially children, can lead to outbreaks of dangerous infections (measles, scarlet 
fever, diphtheria, poliomyelitis, tetanus). According to the State Sanitary and Epidemiological Service of Ukraine, in 2010-2013 the need in vaccines was satisfied only by $60-70 \%$ (the norm was not less than $95.0 \%)$, while the supply of them was nonrhythmic (Щорічна доповідь..., 2015). The risk for the population of Donbass to overdue or not to get at all the necessary vaccination is higher.

Despite the different marks of the significance and risk of the polio disease of two children in Transcarpathia in September 2015 (caused by a virus derived from the vaccine strain), it is undeniable that the coverage level of children vaccination against polio in Ukraine is extremely low - in 2014 only 49\%, for the first half of 2015-14.1\% (МО3 підтверджує..., 2015), and this threatens to be a large epidemic in the future. By the results of the national immunization coverage survey conducted by WHO and UNICEF in 2016, there are still 8 countries where the coverage of three doses of vacine against diphtheria, tetanus and kidney (DTP) is below 50\%. This is Equatorial Guinea, Nigeria, South Sudan, Syria, Somalia, the Central African Republic, Chad and Ukraine (1 in 10 infants..., 2017).

At the high-level round table on the theme of immunization, organized by the Ministry of Health Care of Ukraine and UNICEF on the occasion of the World Polio Day (24.10.2016), Vice-Prime Minister Mr. Rosenko declared that the question of immunization increade to be an important and one of the priorities of the government, as well as questions of national security. After all, according to the Ministry of Health, in August 2016, only 30\% of children in Ukraine were fully immunized against measles, $10 \%$ against hepatitis $B$, and $3 \%$ against diphtheria, pertussis and tetanus. In addition, only $44 \%$ of children under the age of 18 mounths were fully vaccinated against poliomyelitis (Віце-прем'єр-міністр..., 2016).

The deterioration of the sanitary and epidemiological situation, in our opinion, is the most significant (after a direct threat to life during the conduct of hostilities) risk to the health of the population both for the whole country and Donbass, as well as for the restoration of economic activity in these territories.

Undoubtedly, in emergencies, hospitals and medical institutions of all types are faced with a sharp increase in demand for their services. Immediate access to high-quality care is a determinant factor in reducing the number of deaths. Medical institutions have to work in a mode that is very different from the usual one, or by providing unusual help (in peaceful conditions, for example, not every surgeon has experience of hardships for gunshot wounds, contusions). Switching is not easy, because it requires reorganization of the provision of services, employee work, personnel management and attitude towards people. It is also necessary to coordinate activities with a wide range of non-hospital partners (military, volunteers, international and domestic civic organizations, the media, etc.). So, physicians from regions neighboring the Donbas took a huge burden on their shoulders. Since the beginning of the conflict, a significant number of both wounded and civilian soldiers from the combat zone have been brought to Dnipropetrovsk hospitals, which has led to a sharp increase in drug requirements, staff and burden on staff and infrastructure. Accordingly, the region shifted to the leading place in the ranking for prevalence and morbidity, occupying in 2015 first, in 2016 - second place (Fig. 1).

The management of public health protection face the task to develop and bring to the attention of management the algorithm of actions in specific emergency situations with a clear definition of the order and content of activity and performers. Such algorithms should be provided with the necessary material resources and assimilated (through the training system) to the automatic execution.

Reduction of functional and structural vulnerability of medical institutions - including due to the creation of backup water supply lines and heat supply - is obligatory for ensuring the continuity of their activities.

The system for alerting and assisting in emergencies, including possible sabotage, terrorist acts, needs to be improved. Some steps in this direction are already taken. So, in 2015, a single operational-dispatch service of the center of emergency medical aid and disaster medicine was opened in Kherson (На Херсонщині..., 2015).

A separate task is to minimize the losses due to fighting through the provision of timely and effective medical care and, what is equally important, the organization of conditions for the fulfillment of military duty (sanitary and hygiene, adequate nutrition and uniforms, prevention of injuries of non-military character and offenses, etc.).

In May 2015, were held in Verkhovna Rada of Ukraine parliamentary hearings (ukr. Про військовомедичну доктрину України; eng. On the militarymedical doctrine of Ukraine), where the draft doctrine prepared by the Ministry of Defense (MO) for the performance of the Presidential Decree of 14.11.2014 was discussed. During the parliamentary hearings were observed various models of military medical doctrine. According to O. Bogomolets, the military-medical doctrine is a system of views and knowledge that will save lives of military and civilians, both in military and in peacetime, at the expense of 


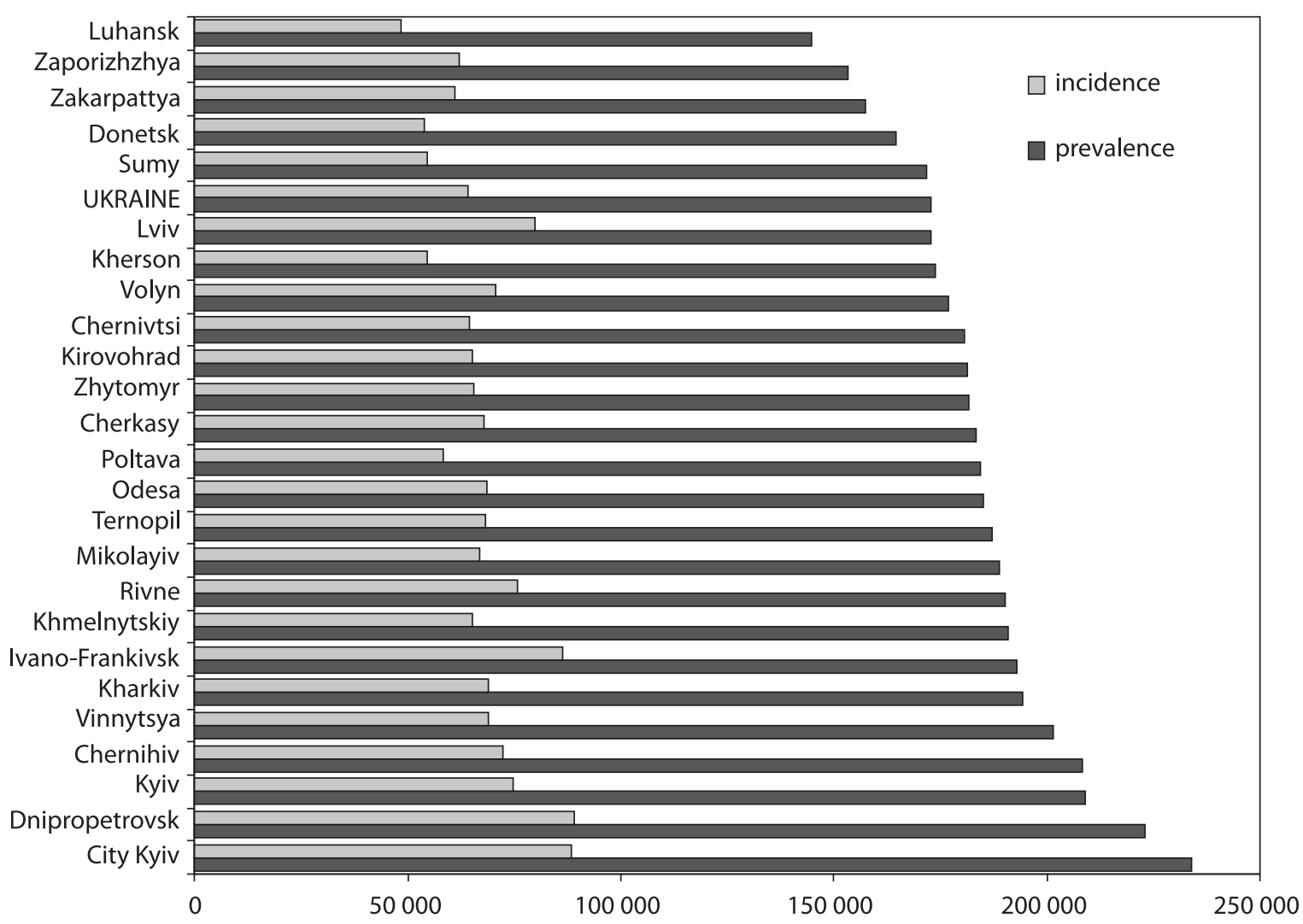

Fig. 1. Incidence and prevalence of diseases (A00-T98) among total population per 100,000 population, by territorial and administrative unit, 2016.

Source: Щорічна доповідь..., 2017.

awareness of each the duty to the state and society, the exact knowledge of their place in the mechanism of joint actions and deliberate skilled cooperation in a definite coordinate system. Specialists of the MO stopped on problems in medical care during the ATO (lack of unified individual medical devices, modern means of finding wounded, armored sanitary transport, autostrading, mobile radiological rooms, outdated medical equipment, etc.). The doctrine was approved by the Verkhovna Rada of Ukraine from November 25, 2015, No. 827-VIII (Постанова..., 2015).

As emphasized by the Extraordinary and Plenipotentiary Ambassador of Israel to Ukraine E. Belotserkovsky, the main principle of Israel medicine (20 травня..., 2015) is the saving lives of every soldier, and this has not only universal value, but also practical value - servicemen are not afraid to risk their lives, because they know that everything possible will be done in order to prevent their death. Therefore, the military medical doctrine of Israel is based on three principles - a combination of military and civilian medical services, provided with a budget for the use of the most effective medicines and equipment and as close as possible to the battlefield of medical assistance. Today there is an exchange of experience with Ukrainian partners (in particular, trainings for psychologists who are working with victims of post-traumatic syndrome).

Assistance to the wounded and victims as a result of the antiterrorist operation requires significant amount of money, trained personnell, necessary equipment and medicines. The increase in the number of combatants increases the need for rehabilitation (physical and mental) and medical and social assistance (see Матяш, Марченко, 2016).

Negative consequences for public health can be both simultaneous and felt in the long run. Losses of life, health and human sufferings associated with military actions, forced displacements, food and drug deficits, outbreaks of diseases, violations of human rights and dignity of a person take place not only directly during a social conflict. N. Boney from the Bureau of Crisis Prevention and Recovery UNDP believes that long-term damage to people and for the development of society may be even greater than direct damage (Building..., 2014). It should be aware that the sphere of negative influence also affects future life, especially this concerns mental and social health. Both during and after emergencies increases the risk of mental health problems. Separated families, children lose opportunities for education, 
adults - decent work, suddenly (and for a long period!) can almost disappear the most important social and health services, which fatally causes significant damage to mental health. A separate problem is the adaptation to the peaceful life of veterans who received significant psychological injuries while taking part in hostilities. We must prepare for the "Donbass" syndrome (like Vietnamese, Afghan and Chechen) today.

International agencies of humanitarian help are doing all they can to help people meet their psychosocial support needs immediately after an emergency, but efforts should be made to strengthen the national mental health system in the long term, using the help and experience of the international community. These possibilities should not be overlooked, since mental, neurological, narcological disorders in the background of seemingly more important problems, pay less attention. However, it is mental health that plays a significant role in the overall well-being and productivity of people, communities and countries those are recovering from emergencies. For example, after a war and a civil conflict in Kosovo, rapid political changes have created an opportunity to reform the mental health system. A new strategic plan has been drawn up to guide and coordinate these efforts, and today, a wide range of mental health services is provided in each of the districts at the level of local communities (Building..., 2014). Guidelines for assessing and providing assistance in acute stress disorder, posttraumatic stress disorder and hardship in nonspecialized medical facilities (mhGAP..., 2013) will be useful for Ukraine in the area of mental health of the WHO Action Program for Ukraine. According to WHO experts, the humanitarian crisis in Ukraine has affected approximately 5 million people and led to the displacement of 1.6 million. The awareness and support of the international community, as well as ongoing funding, are critical to responding to this health emergency. The following are areas of great concern that require immediate mobilization and action: low vaccination coverage; poor communicable diseases surveillance; inadequate access to medications for cancer patients; and lack of access to mental health and rehabilitation care (Health response..., 2017).

\section{Summary}

Reliable, well-trained and well-managed health care system can effectively help to prevent the growth of specific health emergency situations during a crisis of public safety.
The main task for public administration with the aim of minimizing the negative impact of social conflict on the health of the population (both in modern and in the future) should be the transition from the current crisis response policy to a comprehensive long-term strategy to prevent life and health (of course, with the simultaneous resolution of the conflict and the restoration of the economy and the social sphere).

To this end, existing and potential risks to public health and the national health system should be assessed; identify those that can really be influenced (at the state and industry levels) and consistently lobby interests aimed at the survival of the Ukrainian people and the health care system in the development and realization of anti-crisis politics of the state.

The most important tasks facing public health are: effective control of the sanitary and epidemiological situation, prevention of epidemics of infectious diseases (first of all, with emphasis on ensuring the planned immunization of the population (coverage level, completeness, timeliness and quality of drugs); organization provided with the necessary personnel and material resources of actions in emergency situations of various kinds, which carry a potential danger to life and health, provision of urgent needs in services of health protection both for the general population and combatants and victims during their civil conduct.

\section{References}

1 in 10 infants worldwide did not receive any vaccinations in 2016, 2017, World Health Organization, http://www.who. int/mediacentre/news/releases/2017/infants-worldwidevaccinations/en/ [17.07.2017].

20 травня 2015 року у Верховній Раді України відбулися парламентські слухання на тему: "Про військово-медичну доктрину України", 2015, http://iportal.rada.gov. ua/print/109944.html [21.05.2015].

Building Back Better. Sustainable mental health care after emergencies, 2014, WHO, Geneva.

Health response to the humanitarian crisis in Ukraine (2017) http://www.euro.who.int/en/health-topics/emergencies/ health-response-to-the-humanitarian-crisis-in-ukraine/ health-response-to-the-humanitarian-crisis-in-ukraine 01.09.2017

mhGAP module Assessment Management of Conditions Specifically Related to Stress, 2013, WHO, Geneva.

Rockenschaub G., Pukkila J., Profili M.C. (eds.), 2007, Пуmu повышения безопасности здоровья населения, ВОО3 Европейское региональное бюро, Copenhagen.

Віче-прем'єр-міністр України П. Розенко, представники українського Уряду та Адміністрачії Президента заявили про свій намір відновити планову програму іму- 
нізачії в Україні, 2016, МОЗ України, http://moz.gov.ua/ ua/portal/pre_20161024_a.html [24.10.2016].

Ворона В., Шульга М. (eds.), 2016, Українське суспільство 1992-2016. Стан та динаміка змін. Сочіологічний моніторинг, IC НАН України, Київ.

Інтерв'ю голови місії ООН з моніторингу ситуації з прав людини в Україні, 2015, Радіо Свобода, http://www. radiosvoboda.org/content/article/26880181.html [03.03.2015].

Коваленко В.М., Корнацький В.М. (eds.), 2015, Стрес і хвороби системи кровообігу, ДУ «ННЦ «Інститут кардіології ім. акад. М.Д. Стражеска», Київ.

Матяш М.М., Марченко О.М. 2016, Український синдром: медико-психологічний аспект, Видавництво «Артек», Київ.

MO3 підтверджує спалах поліомієліту в Україні, 2015, МО3, https://www.moz.gov.ua/ua/portal/pre_20150903_b. html [03.09.2015].

На Херсонщині діятиме єдина оперативно-диспетчерська служба чентру екстреної медичної допомоги і медицини катастроф, 2015, Прес-служба МОЗ України, http://moz.gov.ua/ua/portal/pre_20151022_f.html [22.10.2015].

Оперативна інформачія щодо ситуачії з програмами профілактики та лікування ВІЛ/ТБ/ВГС/ЗПТ у Донецькій та Луганській областях (на 01.04.2015), 2015, МБФ «Міжнародний Альянс з ВІЛ/СНІД в Україні», http:// www.aidsalliance.org.ua/ru/news/pdf/01-12_2015/04/ SitRep_01042015_final.pdf [20.11.2016].

Постанова Верховної Ради України від 25 листопада 2015 року № 827-VIII «Про Рекомендації парламентських слухань на тему: «Про військово-медичну доктрину України», 2015, Відомості Верховної Ради України оn December 18, 2015. - № 51, page 2495, article 477.

Сайт проекту "Допоможемо ТВ Гуманитарная карта ситуации и потребностей Донецкой и Луганской областей, 2015, http://map.dopomozhemo.tv/?lang=en [10.11.2015].

Сайт проекту «Книга Пам'яті», 2017, http:// http:// memorybook.org.ua/indexfile/statmonth.htm memorybook.org.ua/indexfile/statistic.htm [01.11.2017].

Страх як міріло якості життя (Результати моніторингу інституту соціології НАНУ «Українське суспільство-2014», 2014, http://e-news.com.ua/show/352810. html [20.10.2014].

Щорічна доповідь про стан здоров'я населення, санітарно- епідемічну ситуачію та результати діяльності системи охорони здоров'я України. 2016 рік, 2017, МО3 України, ДУ «УІСД МОЗ України», Київ. 